\title{
The 1891-1920 birth cohort of Quebec chrysotile miners and millers: mortality 1976-88
}

\author{
J C McDonald, F D K Liddell, A Dufresne, A D McDonald
}

\begin{abstract}
A cohort of some 11000 men born 1891-1920 and employed for at least one month in the chrysotile mines and mills of Quebec, was established in 1966 and has been followed ever since. Of the 5351 men surviving into 1976, only 16 could not be traced; 2508 were still alive in 1989, and 2827 had died; by the end of 1992 a further 698 were known to have died, giving an overall mortality of almost $80 \%$. This paper presents the results of analysis of mortality for the period 1976 to 1988 inclusive, obtained by the subject-years method, with Quebec mortality for reference. In many respects the standardised mortality ratios (SMRs) 20 years or more after first employment were similar to those for the period 1951-75-namely, all causes 1.07 (1951-75, 1.09); heart disease 1.02 (1.04); cerebrovascular disease $1.06(1.07)$; external causes 1.17 (1.17). The SMR for lung cancer, however, rose from 1.25 to 1.39 and deaths from mesothelioma increased from eight (10 before review) to 25; deaths from respiratory tuberculosis fell from 57 to five. Among men whose exposure by age 55 was at least 300 million particles per cubic foot $\times$ years (mpcf.y), the SMR (all causes) was elevated in the two main mining regions, Asbestos and Thetford Mines, and for the small factory in Asbestos; so were the SMRs for lung cancer, ischaemic heart disease, cerebrovascular disease, and respiratory disease other than pneumoconiosis. Except for lung cancer, however, there was little convincing evidence of gradients over four classes of exposure, divided at 30,100 ,
\end{abstract}

School of Occupational Health, McGill University, Montreal, Canada

J C McDonald, A Dufresne, A D McDonald

Department of Epidemiology and Biostatistics, McGill University, Montreal, Canada

F D K Liddell and 300 mpcf.y. Over seven narrower categories of exposure up to 300 mpcf.y the SMR for lung cancer fluctuated around $1 \cdot 27$ with no indication of trend, but increased steeply above that level. Mortality from pneumoconiosis was strongly related to exposure, and the trend for mesothelioma was not dissimilar. Mortality generally was related systematically to cigarette smoking habit, recorded in life from $99 \%$ of survivors into 1976; smokers of 20 or more cigarettes a day had the highest SMRs not only for lung cancer but also for all causes, cancer of the stomach, pancreas, and larynx, and ischaemic heart disease. For lung cancer SMRs increased fivefold with smoking, but the increase with dust exposure was comparatively slight for non-smokers, lower again for ex-smokers, and negligible for smokers of at least 20 cigarettes a day; thus the asbestos-smoking interaction was less than multiplicative.

Of the 33 deaths from mesothelioma in the cohort to date, 28 were in miners and millers and five were in employees of a small asbestos products factory where commercial amphiboles had also been used. Preliminary analysis also suggests that the risk of mesothelioma was higher in the mines and mills at Thetford Mines than in those at Asbestos. More detailed studies of these differences and of exposure-response relations for lung cancer are under way.

(British fournal of Industrial Medicine 1993;50:1073-1081)

At a meeting in New York in 1964 of the Working Group on Asbestos and Cancer of the International Union against Cancer, ${ }^{1}$ it was recommended that priority should be given to research on the health effects of exposure to the various types of asbestos fibre and to the elucidation of exposure-response relations. As a consequence of this and at the invitation of the Canadian government a comprehensive series of studies, directed at all aspects of exposure to chrysotile asbestos, was begun by our 
group at McGill University in 1966, initially with support from the Institute of Occupational and Environmental Health of the Quebec Asbestos Mining Association and later from other granting agencies. Over the past 25 years this research programme has widened in scope to include the effects of exposure to amphibole fibres and other types of industry. Central to this endeavour has been the continuing observation of mortality in a large birth cohort of about 11000 men (and some 440 women) defined as all persons, born between 1891 and the end of 1920, who were known to have been employed at any time in the Quebec chrysotile production industry for one month or more. Much emphasis has been put on the optimal use of all available dust measurements to evaluate for each cohort member his exposure to asbestos dust in terms of duration, intensity, and timing.

Findings on mortality have been published on four occasions, the first based on 2413 deaths to November $1966,{ }^{2}$ the earliest in 1910 , and subsequently on 3216 deaths to $1970,{ }^{3}$ then 4037 deaths to $1974,{ }^{4}$ and most recently on 4463 deaths to $1976 . .^{5}$ Over this period, the discovery that some men had more than one work record with slightly different identifying details (name, forename or initials, date of birth) has led gradually to a reduction in the number of men in the cohort from 11323 in 1966 to 10939 by the end of 1975 . No trace was ever found of 1026 men $(9 \cdot 4 \%)$, most after less than 12 months' employment before 1930, and a further $64(0.6 \%)$ had been lost to follow up; 4463 were thought to have died; and 5387 to have survived to 1976. It was later found that there had been a further reduction by 14 because of better identification and 22 additional deaths among those reported alive. This brought our best estimates of cohort size to 10925 men and of survivors to 5351 .

A decision to extend the follow up again, until the end of 1989 , was made for two main reasons: (1) to increase the body of data on all types of malignant disease for analysis of exposure-response by the more advanced techniques now available, ${ }^{6}$ and (2) to study further the nature of the interaction between exposures to asbestos and tobacco smoke with information on smoking habit taken from cohort members while still alive rather than from their relatives after death. It would also be possible to evaluate the hypothesis that the risks of environmentally induced mesothelioma and perhaps lung cancer rise much more than exponentially with time since first exposure. ${ }^{7}$

The findings presented in this paper focus on the broad pattern of mortality in male cohort members who survived into 1976, with analyses by the subject-years method, comparing the numbers of deaths observed against the numbers expected from the experience of the general population of Quebec. This initial approach was chosen to facilitate comparison of the results with those published previously. Later papers will examine in greater detail all aspects of the relations between exposure to asbestos and mesothelioma and lung cancer.

\section{Materials and methods}

ASCERTAINMENT OF DEATHS AND CAUSE OF DEATH The main task of tracing the 5351 surviving men was undertaken primarily by the same two research assistants, one in each of the two main mining regions, who have helped with this work almost since its inception. Additional inquiries had nevertheless to be made through vehicle licencing bureaux and a wide range of social security and other official agencies. All but 16 men $(0.3 \%)$ were traced: 2758 from mines and mills in the region of Thetford Mines; 2158 from the mine and mill in Asbestos; and 419 from the small asbestos products factory in that town; giving a total of 5335 . Table 1 shows the distribution of those alive and dead by place of employment and Table 2 the distribution by year of birth.

Death certificates were found for $98.4 \%$ of the deceased and the codes in the relevant (8th or 9th revision) of the International Classification of Diseases (ICD) allocated by the provincial, state, or national bureau of statistics, about $90 \%$ in Quebec, were recorded. At least some information on the cause of death had been found for 33 of the remaining 46 deaths, and this was coded by two of us (JC $\mathrm{McD}$ and $\mathrm{AD} \mathrm{McD}$ ) as follows: eight deaths to various cancers (ICD codes 145-162); eight to 410-414; six to 819-958; and 11 to other ICD codes. The code 796 or 799 was used for the 13 for whom there was no information as to cause of death; this coding was also used officially for 15 other deaths. An exception to the use of ICD codes was made for mesothelioma, where a "best diagnosis" was made after careful scrutiny of all related clinical, biopsy, and necropsy records. Of the 25 cases identified, 15 were based on a necropsy and 10 on a biopsy; 15 had been coded to ICD 163, the rest to various other codes. In reaching the total number of deaths from pneumoconiosis (48), eight

Table 1 Constitution, at the end of 1988, of the cohort who had survived to 1976

\begin{tabular}{lrrr}
\hline & Alive & \multicolumn{1}{l}{ Dead } & Total \\
\hline Asbestos mine and mill & 1006 & $1152(53 \cdot 4 \%)$ & 2158 \\
Thetford Mines & 1289 & $1469(53 \cdot 3 \%)$ & 2758 \\
Asbestos factory & 213 & $206(49 \cdot 2 \%)$ & 419 \\
Total & 2508 & $2827(53 \cdot 0 \%)$ & $5335^{\star}$ \\
\hline
\end{tabular}

${ }^{\star}$ Excluding the 16 men not traced after 1975 . 
Table 2 Vital status by quinquennium of birth

\begin{tabular}{|c|c|c|c|c|c|c|}
\hline Quinquennium & Alive in 1930 & Lost 1930-76 & Traced & Dead & Alive in 1989 & (\% of traced) \\
\hline $\begin{array}{l}1891-1895 \\
1896-1900 \\
1901-1905 \\
1906-1910 \\
1911-1915 \\
1916-1920\end{array}$ & $\begin{array}{l}1164 \\
1588 \\
1700 \\
1717 \\
1738 \\
1937\end{array}$ & $\begin{array}{l}27 \\
35 \\
25 \\
46 \\
48 \\
39\end{array}$ & $\begin{array}{l}1137 \\
1553 \\
1675 \\
1671 \\
1690 \\
1898\end{array}$ & $\begin{array}{r}1112 \\
1490 \\
1469 \\
1233 \\
1002 \\
810\end{array}$ & $\begin{array}{r}25 \\
63 \\
206 \\
438 \\
688 \\
1088\end{array}$ & $\begin{array}{r}(2 \cdot 2) \\
(4 \cdot 1) \\
(12 \cdot 3) \\
(26 \cdot 2) \\
(40 \cdot 7) \\
(57 \cdot 3)\end{array}$ \\
\hline
\end{tabular}

Table 3 Deaths by age and cause of death

\begin{tabular}{|c|c|c|c|c|c|}
\hline \multirow[b]{2}{*}{ Cause of death (with ICD codes) } & \multicolumn{3}{|c|}{ Deaths observed at ages } & \multirow[b]{2}{*}{ Excess ${ }^{*}$} & \multirow[b]{2}{*}{$S M R$} \\
\hline & $55-74$ & $75-97$ & $55-97$ & & \\
\hline All causes & 1456 & 1371 & 2827 & $192 \cdot 7$ & $1 \cdot 07$ \\
\hline Malignant neoplasms (140-209) & 466 & 321 & 787 & $99 \cdot 3$ & $1 \cdot 14$ \\
\hline Abdominal $(150-159)$ & 106 & 96 & 202 & $-8 \cdot 8$ & 0.96 \\
\hline Oesophagus (150) & 7 & 3 & 10 & $-3 \cdot 7$ & 0.73 \\
\hline Stomach (151) & 33 & 23 & 56 & $8 \cdot 1$ & $1 \cdot 17$ \\
\hline Colon/rectum (152-154) & 34 & 39 & 73 & -15.9 & 0.82 \\
\hline Pancreas (157) & 20 & 17 & 37 & $0 \cdot 7$ & $1 \cdot 02$ \\
\hline Other abdominal $(155-6,158-9)$ & 12 & 14 & 26 & $2 \cdot 0$ & $1 \cdot 08$ \\
\hline \multicolumn{6}{|l|}{ Respiratory: } \\
\hline Larynx (161) & 8 & 10 & 18 & $4 \cdot 2$ & $1 \cdot 30$ \\
\hline Lung (162) & 223 & 98 & 321 & $91 \cdot 3$ & $1 \cdot 40$ \\
\hline \multicolumn{6}{|l|}{ Genitourinary: } \\
\hline Prostate (185) & 42 & 39 & 81 & $4 \cdot 3$ & 1.06 \\
\hline Bladder (188) & 11 & 9 & 20 & $-5 \cdot 0$ & 0.80 \\
\hline Kidney (189) & 7 & 6 & 13 & $0 \cdot 0$ & 1.00 \\
\hline Lymphatic and haematopoietic tissue $(200-208)$ & 26 & 30 & 56 & $8 \cdot 1$ & $1 \cdot 17$ \\
\hline Other (rem 140-209) & 43 & 33 & 76 & $5 \cdot 2$ & 1.07 \\
\hline Mesotheliomat & 20 & 5 & 25 & 25 & - \\
\hline Pneumoconiosis $\dagger$ & 33 & 15 & 48 & 48 & - \\
\hline Other respiratory diseases (rem $460-519)$ & 110 & 146 & 256 & $13 \cdot 0$ & 1.05 \\
\hline \multicolumn{6}{|l|}{ Heart disease: } \\
\hline Ischaemic $(410-414)$ & 433 & 395 & 828 & $18 \cdot 5$ & 1.02 \\
\hline Other $(391,392 \cdot 0,402,404,415-429)$ & 67 & 118 & 185 & $0 \cdot 1$ & 1.00 \\
\hline Cerebrovascular disease $(430-438)$ & 99 & 126 & 225 & $12 \cdot 9$ & 1.06 \\
\hline Chronic liver disease and cirrhosis (571) & 23 & 9 & 32 & -1.8 & 0.95 \\
\hline Alcoholism $(291,303,860)$ & 0 & 0 & 0 & $-5 \cdot 7$ & 0 \\
\hline Injury and poisoning (800-999) & 60 & 29 & 89 & $12 \cdot 8$ & $1 \cdot 17$ \\
\hline All other causes (rem 001-999) & $145(2)$ & $207(3)$ & $352(5)$ & $-29 \cdot 4$ & 0.92 \\
\hline $\begin{array}{l}\text { (including respiratory tuberculosis } \\
\text { in parentheses)) }\end{array}$ & & & & & \\
\hline
\end{tabular}

^Excess of deaths observed at all ages over the number of deaths expected on the basis of death rates for Quebec males; see text. An entry is negative where fewer deaths were observed than expected.

tThese 73 deaths are not included elsewhere in this table; see text.

Rem $=$ Remaining numbers from .

that had been coded in the wrong revision of the ICD were added to the codes in the correct revision. The first three columns of table 3 show deaths by age and cause of death. The 73 deaths ascribed to mesothelioma and pneumoconiosis are shown only once, and not also under the ICD code on the death certificate.

\section{DUST EXPOSURE}

Detailed work histories for each man in the cohort had previously been recorded from the start of the first job (the earliest in 1904) to the end of the last job, or to November 1966 if earlier. These histories were updated to 1985 , mainly from employment or medical records, when the last man retired.

Estimates of dust concentrations, year by year, for each of the more than 5000 jobs in the industry had been made up to November 1966 by Gibbs and Lachance, ${ }^{8}$ based on about 4500 midget impinger dust counts from annual surveys in all companies, 1949-66. In our previous analyses exposure after November 1966 but before 1976 was ignored as any additional contribution would have been small and probably too late to affect the outcome. Although dust concentrations continued to fall after 1966 it was considered that some allowance had to be made for exposure over potentially two decades. An attempt to adopt the same 
approach as Gibbs and Lachance proved too difficult, mainly due to enormous changes in the industry during these years, to a lack of sources of information, and to a lack of appropriate or comparable measurements. There was sufficient information, nevertheless, to estimate the trends in dust concentration, year by year from 1967 onwards. For each of the almost 2500 men in the cohort employed after November 1966, the dust concentration assessed for him at that time was amended on an annual basis in accordance with the trend for his specific mine or mill; exposures were assigned accordingly.

Each man's dust exposure was calculated, in terms of million particles per cubic foot $x$ years (mpcf.y) accumulated to age 55 , because by that age most men in the cohort, or indeed in this industry, would have received a high proportion of their lifetime exposure; and of course all men in the cohort were over 55 by 1976 . The calculation took into account the fraction of the year worked, the average dust concentration for the particular job and year, and the weekly hours worked during the period in question.

\section{SMOKING HISTORIES}

As previously reported, ${ }^{5}$ smoking habit had been obtained by questionnaire in 1970. Proxies had responded for $93 \%$ of those who had died since 1950 , but for $99.6 \%$ of those alive in 1970 , including all survivors to 1976, the questionnaire had been completed by the subject himself. Each man has been classified according to cigarette smoking at the time of his report as: non-smoker of cigarettes (1010 men); ex-smoker (1138); current, $<20$ a day (1119); and current, $\geqslant 20$ a day (1795). It was not feasible to allocate 273 men to any of these classes.

\section{STATISTICAL ANALYSIS}

Analyses of mortality for 1976 to the end of 1988 were made by the subject-years method, ${ }^{9}$ with the PYRS program, ${ }^{10}$ Quebec death rates were used as a reference ${ }^{11}$; rates for the six year period $1980-5$, the latest available, were replicated to give estimates for 1986, 1987, and 1988. The numbers of deaths observed $(\mathrm{O})$ were compared with the numbers expected (E) from the experience of the general population of Quebec by means of $\mathrm{O} / \mathrm{E}$ ratios, and we follow the usual practice of terming them standardised mortality ratios (SMRs). Study interval has been defined as that period over which each subject is studied in a particular aspect of the analysis, ${ }^{4}$ and only for table 3 did each subject's interval start on 1 January 1976. For tables 4 to 9 the start was at 20 years after first employment in the industry: there were 200 men whose record of first employment was after 1955; of these 52 were at Mine 5, which started operations, near Thetford, only in November 1965. There had been 27 deaths before the starts of study intervals and these were excluded from the analyses; subject-years for the remaining 173 men were accumulated only after 20 years had elapsed. Of the 27 deaths, 22 were men from Mine 5; five of these were from pneumoconiosis, five from lung cancer, eight from ischaemic

Table 4 Deaths from all causes by place of employment and in relation to exposure accumulated to age 55

\begin{tabular}{|c|c|c|c|c|c|}
\hline \multirow[b]{2}{*}{ Exposure (mpcf.y) } & \multirow[b]{2}{*}{ Men } & \multirow{2}{*}{$\begin{array}{l}\text { Man-years } \\
\text { (000s) }\end{array}$} & \multicolumn{2}{|c|}{ Deaths } & \multirow[b]{2}{*}{$S M R$} \\
\hline & & & $O$ & $E$ & \\
\hline $\begin{array}{l}\text { Asbestos mine anc } \\
<30 \\
30,<100 \\
100,<300 \\
\geqslant 300\end{array}$ & $\begin{array}{l}926 \\
494 \\
369 \\
338\end{array}$ & $\begin{array}{l}8 \cdot 68 \\
4 \cdot 80 \\
3 \cdot 63 \\
3 \cdot 10\end{array}$ & $\begin{array}{l}512 \\
241 \\
182 \\
195\end{array}$ & $\begin{array}{l}520 \cdot 2 \\
251 \cdot 2 \\
181 \cdot 6 \\
153 \cdot 2\end{array}$ & $\begin{array}{l}0.98 \\
0.96 \\
1 \cdot 0 \\
1 \cdot 27\end{array}$ \\
\hline Total & 2127 & $20 \cdot 20$ & 1130 & $1106 \cdot 2$ & $1 \cdot 02$ \\
\hline $\begin{array}{l}\text { Thetford Mines: } \\
<30 \\
30,<100 \\
100,<300 \\
\geqslant 300\end{array}$ & $\begin{array}{l}844 \\
497 \\
619 \\
704\end{array}$ & $\begin{array}{l}7 \cdot 81 \\
4 \cdot 74 \\
6 \cdot 07 \\
6 \cdot 50\end{array}$ & $\begin{array}{l}447 \\
243 \\
308 \\
415\end{array}$ & $\begin{array}{l}440 \cdot 7 \\
220 \cdot 4 \\
282 \cdot 6 \\
307 \cdot 9\end{array}$ & $\begin{array}{l}1 \cdot 01 \\
1 \cdot 10 \\
1.09 \\
1 \cdot 35\end{array}$ \\
\hline Total & 2664 & $25 \cdot 11$ & 1413 & $1251 \cdot 6$ & $1 \cdot 13$ \\
\hline $\begin{array}{l}\text { Asbestos factory: } \\
<30 \\
30,<100 \\
100,<300 \\
\geqslant 300\end{array}$ & $\begin{array}{r}232 \\
103 \\
61 \\
20\end{array}$ & $\begin{array}{l}2 \cdot 30 \\
1 \cdot 03 \\
0 \cdot 62 \\
0 \cdot 13\end{array}$ & $\begin{array}{r}111 \\
44 \\
30 \\
18\end{array}$ & $\begin{array}{r}123 \cdot 6 \\
47 \cdot 8 \\
27 \cdot 5 \\
6 \cdot 5\end{array}$ & $\begin{array}{l}0.90 \\
0.92 \\
1.09 \\
2.76\end{array}$ \\
\hline Total & 416 & $4 \cdot 08$ & 203 & $205 \cdot 4$ & 0.99 \\
\hline
\end{tabular}

The columns headed $\mathrm{O}, \mathrm{E}$, and SMR, give respectively: the numbers of deaths of men, 20 years or more after first employment, occurring during 1976-88; the numbers expected on the basis of male mortality in Quebec; and the O/E ratios; see text. Excluded are 54 deaths among 101 men whose start of employment was recorded as after age 45. 
heart disease, and five from miscellaneous causes. A further exclusion was of 101 men who had not started employment by the age of 45 ; they were mainly caretakers who had been recruited from exemployees known to management. The 273 men not classified according to smoking habit were also excluded from tables 7 and 8.
Results

GENERAL MORTALITY

Table 3 shows that the 2827 deaths observed in cohort members from 1976 to the end of 1988 , were divided fairly equally between men aged 55-74 and 75-97. Certain causes-lung cancer, mesothelioma, pneumoconiosis, injury, and poi-

Table 5 Deaths by selected causes and place of employment in relation to exposure accumulated to age 55

\begin{tabular}{|c|c|c|c|c|c|c|c|c|}
\hline \multirow{3}{*}{$\begin{array}{l}\text { Cause of death } \\
\text { (with ICD codes) }\end{array}$} & \multicolumn{8}{|c|}{ Exposure (mpcf.y) } \\
\hline & \multicolumn{2}{|l|}{$<30$} & \multicolumn{2}{|c|}{$30,<100$} & \multicolumn{2}{|c|}{$100,<300$} & \multicolumn{2}{|c|}{$\geqslant 300$} \\
\hline & $O$ & $S M R$ & $O$ & $S M R$ & $O$ & $S M R$ & $O$ & $S M R$ \\
\hline \\
\hline \multicolumn{9}{|l|}{ Stomach $(151)$} \\
\hline Asbestos mine and mill & 12 & $1 \cdot 29$ & 5 & $1 \cdot 10$ & 1 & $0 \cdot 30$ & 4 & $1 \cdot 39$ \\
\hline Asbestos factory & 1 & 0.45 & 3 & $3 \cdot 42$ & 0 & 0 & 0 & 0 \\
\hline Complete cohort & 23 & $1 \cdot 18$ & 12 & $1 \cdot 26$ & 9 & $1 \cdot 00$ & 12 & $1 \cdot 39$ \\
\hline \multicolumn{9}{|l|}{ Pancreas (157): } \\
\hline Asbestos mine and mill & 6 & 0.90 & 3 & 0.87 & 5 & 1.97 & 2 & 0.90 \\
\hline Thetford Mines & 6 & $1 \cdot 02$ & 4 & $1 \cdot 25$ & 2 & $0 \cdot 49$ & 7 & 1.59 \\
\hline Asbestos factory & 1 & 0.60 & 1 & 1.44 & 0 & 0 & 0 & 0 \\
\hline Complete cohort & 13 & 0.91 & 8 & 1.09 & 7 & 0.99 & 9 & $1 \cdot 34$ \\
\hline \multicolumn{9}{|l|}{ Larynx (161): } \\
\hline Asbestos factory & 3 & $4 \cdot 69$ & 0 & 0 & 0 & 0 & 0 & 0 \\
\hline Complete cohort & 9 & $1 \cdot 66$ & 1 & 0.36 & 3 & $1 \cdot 11$ & 4 & $1 \cdot 57$ \\
\hline \multicolumn{9}{|l|}{ Lung (162): } \\
\hline Asbestos mine and mill & 61 & 1.49 & 28 & $1 \cdot 29$ & 22 & $1 \cdot 36$ & 22 & $1 \cdot 55$ \\
\hline Thetford Mines & 37 & $1 \cdot 01$ & 36 & 1.73 & 28 & $1 \cdot 05$ & 54 & $1 \cdot 89$ \\
\hline Asbestos factory & 11 & 1.05 & 5 & $1 \cdot 11$ & 2 & 0.72 & 4 & $7 \cdot 00$ \\
\hline Complete cohort & 109 & $1 \cdot 24$ & 69 & 1.46 & 52 & $1 \cdot 14$ & 80 & $1 \cdot 85$ \\
\hline \multicolumn{9}{|l|}{ Prostate $(185)$} \\
\hline Asbestos mine and mill & 22 & $1 \cdot 36$ & 10 & $1 \cdot 36$ & 6 & $1 \cdot 16$ & 4 & 0.94 \\
\hline Thetford Mines & 18 & $1 \cdot 34$ & 4 & 0.66 & 4 & 0.52 & 9 & $1 \cdot 06$ \\
\hline Asbestos factory & 3 & $0 \cdot 81$ & 0 & 0 & 0 & 0 & 0 & 0 \\
\hline Complete cohort & 43 & $1 \cdot 29$ & 14 & 0.95 & 10 & $0 \cdot 73$ & 13 & $1 \cdot 01$ \\
\hline \multicolumn{9}{|l|}{ Kidney (185): } \\
\hline Asbestos mine and mill & 3 & $1 \cdot 25$ & 0 & 0 & 2 & $2 \cdot 21$ & 2 & $2 \cdot 54$ \\
\hline Thetford Mines & 1 & 0.47 & 0 & 0 & $\overline{3}$ & $2 \cdot 05$ & $\overline{1}$ & 0.63 \\
\hline Asbestos factory & 0 & 0 & 0 & 0 & 0 & 0 & 0 & 0 \\
\hline Complete cohort & 4 & $0 \cdot 78$ & 0 & 0 & 5 & 1.99 & 3 & $1 \cdot 26$ \\
\hline \multicolumn{9}{|l|}{$\begin{array}{l}\text { Lymphatic and haematopoletic } \\
\text { tissue }(200-208)\end{array}$} \\
\hline Asbestos mine and mill & 12 & $1 \cdot 31$ & 6 & $1 \cdot 32$ & 2 & $0 \cdot 60$ & 4 & $1 \cdot 40$ \\
\hline Thetford Mines & 5 & 0.63 & 7 & 1.69 & 8 & 1.52 & 6 & $1 \cdot 05$ \\
\hline Asbestos factory & 4 & $1 \cdot 78$ & 0 & 0 & 1 & $1 \cdot 88$ & 0 & 0 \\
\hline Complete cohort & 21 & $1 \cdot 09$ & 13 & $1 \cdot 36$ & 11 & $1 \cdot 21$ & 10 & $1 \cdot 15$ \\
\hline \multicolumn{9}{|c|}{ Ischaemic heart disease $(410-414)$} \\
\hline Asbestos mine and mill & 129 & $0 \cdot 82$ & 66 & 0.86 & 54 & 0.97 & 56 & $1 \cdot 17$ \\
\hline Thetford Mines & 131 & 0.98 & 79 & $1 \cdot 15$ & 104 & $1 \cdot 18$ & 119 & $1 \cdot 24$ \\
\hline Asbestos factory & 42 & $1 \cdot 11$ & 10 & 0.67 & 8 & 0.92 & 6 & $2 \cdot 92$ \\
\hline Complete cohort & 302 & 0.92 & 155 & 0.97 & 166 & $1 \cdot 09$ & 181 & $1 \cdot 24$ \\
\hline \multicolumn{9}{|c|}{ Cerebrovascular disease $(430-438)$} \\
\hline Asbestos mine and mill & 35 & $0 \cdot 79$ & 13 & 0.64 & 10 & $0 \cdot 70$ & 17 & $1 \cdot 42$ \\
\hline Thetford Mines & 34 & 0.93 & 18 & $1 \cdot 07$ & 32 & $1 \cdot 47$ & 40 & $1 \cdot 68$ \\
\hline Asbestos factory & 12 & $1 \cdot 19$ & 1 & $0 \cdot 27$ & 2 & 0.99 & 2 & 3.78 \\
\hline Complete cohort & 81 & 0.89 & 32 & 0.79 & 44 & $1 \cdot 16$ & $5 \overline{9}$ & $1 \cdot 62$ \\
\hline \multicolumn{9}{|c|}{$\begin{array}{l}\text { Respiratory disease, excluding } \\
\text { pneumoconiosis (rem 460-519) }\end{array}$} \\
\hline Asbestos mine and mill & 65 & $1 \cdot 30$ & 24 & $1 \cdot 03$ & 16 & 0.96 & 20 & $1 \cdot 46$ \\
\hline Thetford Mines & 41 & 0.98 & 18 & 0.92 & 20 & $0 \cdot 80$ & 31 & $1 \cdot 13$ \\
\hline Asbestos factory & 5 & 0.43 & 5 & $1 \cdot 18$ & 1 & 0.42 & 1 & 1.73 \\
\hline Complete cohort & 111 & $1 \cdot 07$ & 47 & $1 \cdot 00$ & 37 & $0 \cdot 84$ & 52 & $1 \cdot 25$ \\
\hline
\end{tabular}

For explanations, see footnote to Table 4. 
Table 6 Deaths from lung cancer in relation to exposure accumulated to age 55

\begin{tabular}{|c|c|c|c|c|}
\hline \multirow{2}{*}{$\begin{array}{l}\text { Exposure } \\
\text { (mpcf.y) }\end{array}$} & \multirow[b]{2}{*}{ Men } & \multicolumn{2}{|c|}{ Deaths } & \multirow[b]{2}{*}{$S M R(95 \% C I)$} \\
\hline & & $O$ & $E$ & \\
\hline $\begin{array}{l}<3 \\
3,<10 \\
10,<30 \\
30,<60 \\
60,<100 \\
100,<200 \\
200,<300 \\
300,<400 \\
400,<1000 \\
\geqslant 1000\end{array}$ & $\begin{array}{l}708 \\
582 \\
712 \\
569 \\
525 \\
663 \\
386 \\
253 \\
621 \\
188\end{array}$ & $\begin{array}{l}36 \\
40 \\
33 \\
39 \\
30 \\
32 \\
20 \\
16 \\
42 \\
22\end{array}$ & $\begin{array}{r}31 \cdot 4 \\
25 \cdot 3 \\
31 \cdot 3 \\
24 \cdot 4 \\
22 \cdot 8 \\
28 \cdot 3 \\
17 \cdot 3 \\
10 \cdot 7 \\
25 \cdot 4 \\
7 \cdot 2\end{array}$ & $\begin{array}{l}1.14(0.80,1.58) \\
1.58(1.13,2.15) \\
1.05(0.73,1.48) \\
1.60(1.14,2.19) \\
1.32(0.89,1.88) \\
1.13(0.77,1.60) \\
1.15(0.71,1.78) \\
1.50(0.86,2.44) \\
1.65(1.19,2.23) \\
3.04(1.90,4.60)\end{array}$ \\
\hline Total & 5207 & 310 & $224 \cdot 1$ & $1.38(1.23,1.55)$ \\
\hline
\end{tabular}

For explanations see footnotes to table 4.

soning - were at least twice as common, however, in the younger age group. There was a small excess of deaths from all causes (SMR $=1.07)$ and a substantial excess for lung cancer (SMR $=1 \cdot 40)$. For mesothelioma and pneumoconiosis, where reasonable expected numbers cannot be derived from mortality in the general population, proportional death rates were $0.9 \%$ and $1 \cdot 7 \%$. Deaths from most other causes were close to expectation, notably the abdominal neoplasms $(S M R=0.96)$, with only stomach cancer slightly in excess (SMR $=1 \cdot 17 ; \mathrm{p}=0 \cdot 27$.

\section{EXPOSURE-RESPONSE}

In this section, exposure was that accumulated to age 55, divided in most tables into four classes at 30,100 , and 300 mpcf.y, and response was mortality from 1976 to 1988 , at least 20 years from first employment. Table 4 shows observed and expected deaths (all causes) by place of employment. There was little or no excess below $100 \mathrm{mpcf}$.y (that which did occur was concentrated at Thetford Mines) and only two small excesses for exposure up to 300 mpcf.y; there were, however, considerable excesses for exposures greater than 300 mpcf.y. Similar analyses in table 5 for causes of special interest showed little convincing evidence of an exposure related gradient in risk. The SMR was highest for exposures greater than 300 mpcf.y for cancer at several sites, and also for ischaemic heart disease, cerebrovascular disease, and non-malignant respiratory diseases other than pneumoconiosis. Having regard to the fact that the only SMR shown in table 3 as being importantly in excess was that for lung cancer, the detail of table 5 is important. The lack of an association with exposure less than 300 mpcf.y at any of the three work locations should be noted; also that men with the highest exposure were everywhere at greater risk.. When exposure was examined in greater detaif without regard to place of employment (table 6)

Table 7 Deaths from selected causes in relation to cigarette smoking

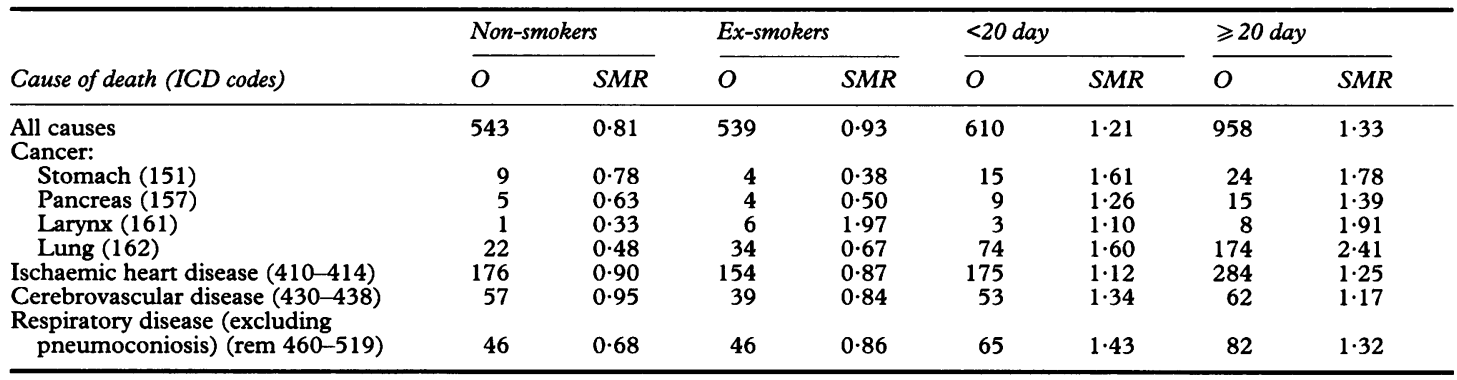

Excluded from this table are 150 deaths among 273 men whose smoking histories were not classified. For explanations and other exclusions see footnote on table 4.

Table 8 Deaths from lung cancer according to exposure accumulated to age 55 and cigarette smoking

\begin{tabular}{|c|c|c|c|c|c|c|c|c|c|c|}
\hline \multirow{2}{*}{$\begin{array}{l}\text { Exposure } \\
\text { (mpcf.y) }\end{array}$} & \multicolumn{2}{|c|}{$\begin{array}{l}\text { Non-smokers of } \\
\text { cigarettes }\end{array}$} & \multicolumn{2}{|c|}{$\begin{array}{l}\text { Ex-smokers and } \\
<20 \text { cigarettes/day }\end{array}$} & \multicolumn{2}{|c|}{$\begin{array}{l}\geqslant 20 \\
\text { cigarettes/day }\end{array}$} & \multicolumn{2}{|c|}{$\begin{array}{l}\text { All smokers } \\
\text { of cigarettes }\end{array}$} & \multicolumn{2}{|c|}{ Total } \\
\hline & $O$ & $S M R$ & $O$ & $S M R$ & $O$ & $S M R$ & $O$ & $S M R$ & $O$ & $S M R$ \\
\hline $\begin{array}{l}<60 \\
\geqslant 60\end{array}$ & $\begin{array}{l}10 \\
11\end{array}$ & $\begin{array}{l}0.37 \\
0.61\end{array}$ & $\begin{array}{l}44 \\
61\end{array}$ & $\begin{array}{l}0.97 \\
1.21\end{array}$ & $\begin{array}{l}88 \\
85\end{array}$ & $\begin{array}{l}2 \cdot 54 \\
2 \cdot 29\end{array}$ & $\begin{array}{l}132 \\
146\end{array}$ & $\begin{array}{l}1.65 \\
1.67\end{array}$ & $\begin{array}{l}142 \\
157\end{array}$ & $\begin{array}{l}1 \cdot 32 \\
1 \cdot 49\end{array}$ \\
\hline Total & 21 & 0.47 & 105 & 1.09 & 173 & $2 \cdot 41$ & 278 & 1.66 & 299 & $1 \cdot 41$ \\
\hline Asbestos effect & & 1.65 & & 1.25 & & 0.90 & & 1.01 & & $1 \cdot 13$ \\
\hline
\end{tabular}

The asbestos effect ${ }^{12}$ is the ratio of the SMR for exposed workers (taken here as those exposed to 60 or more mpcf.y) to that for the unexposed (taken as exposed to less than 60 mpcf.y); the relative asbestos effect ${ }^{12}$ is the ratio of the asbestos effect for non-smokers to that for smokers, here $1 \cdot 65 / 1 \cdot 01=1 \cdot 6$. 
Table 9 Deaths from pneumoconiosis and mesothelioma by place of employment and exposure accumulated to age 55

\begin{tabular}{|c|c|c|c|c|}
\hline \multirow[b]{2}{*}{ Exposure (mpcf.y) } & \multicolumn{2}{|c|}{ Pneumoconiosis } & \multicolumn{2}{|c|}{ Mesothelioma } \\
\hline & Cases & Rate & Cases & Rate \\
\hline $\begin{array}{l}\text { Asbestos mine an } \\
<100 \\
100,<300 \\
\geqslant 300\end{array}$ & $\begin{array}{l}3 \\
2 \\
5\end{array}$ & $\begin{array}{l}0.22 \\
0.55 \\
1.61\end{array}$ & $\begin{array}{l}2 \\
1 \\
3\end{array}$ & $\begin{array}{l}0.15 \\
0.28 \\
0.97\end{array}$ \\
\hline Total $^{\star}$ & 10 & 0.49 & 6 & 0.29 \\
\hline $\begin{array}{l}\text { Thetford Mines: } \\
<100 \\
100,<300 \\
\geqslant 300\end{array}$ & $\begin{array}{r}3 \\
7 \\
21\end{array}$ & $\begin{array}{l}0 \cdot 24 \\
1 \cdot 15 \\
3 \cdot 23\end{array}$ & $\begin{array}{l}2 \\
6 \\
6\end{array}$ & $\begin{array}{l}0 \cdot 16 \\
0 \cdot 99 \\
0.92\end{array}$ \\
\hline Total ${ }^{\star}$ & 31 & $1 \cdot 22$ & 14 & 0.55 \\
\hline $\begin{array}{l}\text { Asbestos factory: } \\
\quad<100 \\
\geqslant 100\end{array}$ & $\begin{array}{l}0 \\
2\end{array}$ & $\begin{array}{l}0 \\
2 \cdot 67\end{array}$ & $\begin{array}{l}3 \\
2\end{array}$ & $\begin{array}{l}0.90 \\
2.67\end{array}$ \\
\hline Total ${ }^{\star}$ & 2 & 0.49 & 5 & $1 \cdot 22$ \\
\hline
\end{tabular}

See table 4 for numbers of men and of man-years. Rates are per 1000 man-years.

*For these rates, denominators include man-years for men who had not started employment by age 45 .

there was no evidence of a gradient over seven classes of exposure up to $300 \mathrm{mpcf} . \mathrm{y}$, although above that value the risk increased greatly.

\section{SMOKING HABIT}

In contrast with the findings just described the relations between mortality and cigarette smoking were generally strong and systematic (table 7). The degree of interaction between exposure to asbestos and cigarette smoking for lung cancer (table 8) is therefore illuminating: whereas the increase of SMR with smoking was fivefold, from 0.47 to 2.41 , the increase with dust exposure was comparatively slight and somewhat irregular; the asbestos effect ${ }^{12}$ was only 1.13 overall, highest for non-smokers of cigarettes and lowest for smokers of 20 or more cigarettes a day.
PNEUMOCONIOSIS AND MESOTHELIOMA

In the absence of appropriate SMRs for these diseases, crude death rates per 100000 man-years of net service have been computed by place of employment and exposure to age 55 (table 9). The risk of pneumoconiosis increased sharply with increased exposure at each location; there were similar trends for mesothelioma although this was based on few deaths.

\section{Discussion}

The present cohort has been under review, retrospectively and prospectively, for the best part of a century, and of the 9844 men who were alive in 1930, over $72 \%$ had died before 1989 (table 2). From further follow up, we now know of almost 700 deaths from 1989-92, bringing the total mortality to over 7800 , or almost $80 \%$. To the best of our knowledge, only in the study by Enterline et al of 1074 men who retired between 1941 and 1967 from a large asbestos products company, of whom $88 \%$ were known to be deceased at the end of $1980,{ }^{13}$ has this level of mortality been exceeded; it is seldom that occupational cohorts are followed beyond about $20 \%$ mortality. Of the 2690 members of the cohort who were born in the nineteenth century and were traced from 1930, all but 88 ( $3 \%$ ) had died by 1989 , all but $1 \%$ by the end of 1992. Among the 27 known survivors, all over 91 years of age, there were 10 aged between 95 and 98 , and two of 99 years.

It does not seem to be generally appreciated that the results from occupational cohorts cannot be compared unless account is taken of the stage reached in their evolution and the level of mortality observed. Thus it was to be anticipated that the pattern of mortality of survivors into 1976, when the youngest was aged 56 and the oldest 85 , would

Table 10 Deaths from selected causes 20 years or more after first employment, 1951-75 and 1976-88

\begin{tabular}{|c|c|c|c|c|c|c|}
\hline \multirow{2}{*}{$\begin{array}{l}\text { Cause of death } \\
\text { (with ICD codes in 9th revision) }\end{array}$} & \multicolumn{3}{|c|}{$1951-75$} & \multicolumn{3}{|c|}{$1976-88$} \\
\hline & $O$ & $P M R$ & $S M R$ & $O$ & $P M R$ & $S M R$ \\
\hline \multicolumn{3}{|l|}{ Malignant neoplasms: } & 1.09 & 2800 & 100 & $1 \cdot 07$ \\
\hline Abdominal (150-159) & 276 & $8 \cdot 4$ & 1.01 . & 202 & $7 \cdot 2$ & 0.97 \\
\hline Lung (162) & 230 & $7 \cdot 0$ & $1 \cdot 25$ & 315 & $11 \cdot 2$ & $1 \cdot 39$ \\
\hline Mesothelioma ${ }^{\star}$ & 8 & $0 \cdot 2$ & - & 25 & 0.9 & - \\
\hline Other (rem 140-209) & 252 & $7 \cdot 7$ & 1.09 & 263 & $9 \cdot 4$ & 1.07 \\
\hline Heart disease (391-429) & 1332 & $40 \cdot 5$ & 1.04 & 1822 & $65 \cdot 1$ & 1.02 \\
\hline \multicolumn{7}{|l|}{ Respiratory disease: } \\
\hline Tuberculosis (011) & 57 & $1 \cdot 7$ & $1 \cdot 39$ & 5 & $0 \cdot 2$ & $t$ \\
\hline Pneumoconiosis $(500-503,505)$ & 42 & $1 \cdot 3$ & $13 \cdot 55$ & 43 & $1 \cdot 5$ & \\
\hline Other (rem 460-519) & 156 & $4 \cdot 7$ & 0.99 & 255 & $9 \cdot 1$ & $1 \cdot 06$ \\
\hline Cerebrovascular disease $(430-438)$ & 243 & $7 \cdot 4$ & 1.07 & 223 & $8 \cdot 0$ & 1.06 \\
\hline External causes (800-999) & 183 & $5 \cdot 6$ & $1 \cdot 17$ & 87 & $3 \cdot 1$ & $1 \cdot 16$ \\
\hline
\end{tabular}

*Best diagnosis: the number of mesotheliomas $1951-75$ was originally reported as 10 but two cases have been deleted after full review; see text.

tNot calculated.

PMR = proportional mortality ratio, per cent. 
be different from that in earlier years. Although exact comparisons cannot be made, table 10 sets out the distribution of deaths 1951-75 and 1976-88, with proportional mortality ratios (PMRs, \%) and SMRs. The two sets of data presented are similar in both PMR and SMR only for abdominal and "other" malignancies, pneumoconiosis, and stroke. There has been a clear increase in the number of deaths from mesothelioma, an even greater decrease in deaths from pulmonary tuberculosis, presumably in line with national trends, and an increase in lung cancer. The SMRs for heart disease, for "other" respiratory diseases, and for external causes were similar in the two periods, but the PMRs had changed considerably.

The 33 deaths from mesothelioma in the cohort to date, 28 in miners and millers and five in the small subcohort of factory workers, were primarily of the pleura; in one case with low diagnostic probability the peritoneum was also affected. Less than half of these deaths (15) were correctly coded to ICD 163, the remainder to various other codes. The evidence on differences in risk in the two main mining areas and the small asbestos products factory, apparent in table 9, was reinforced in a preliminary analysis. ${ }^{14}$ These 33 cases are the subject of a detailed study to be published separately, with special attention to the possible role of fibrous tremolite and other amphiboles and to exposureresponse. Eventual resolution of these complex aetiological issues will require an extensive survey of lung tissue for fibre analysis.

Meanwhile, the proportional mortality from mesothelioma in chrysotile miners and millers, excluding the factory workers, has reached $0.4 \%$; nevertheless, this is much lower than has already been found in cohorts exposed to commercial amphiboles at a much earlier stage of mortality. In American insulation workers and in South African crocidolite miners, as instances, the corresponding figures had reached $7.7 \%$ and $4.7 \%$, when the overall mortality was still less than $13 \%$ and $17 \%$, respectively. ${ }^{1516}$

Although the SMR for lung cancer has now increased from $1 \cdot 25$ to $1 \cdot 38$, table 6 gave no indication of a trend over seven classes of exposure up to 300 mpcf.y (Spearman rank correlation coefficient $=-0.04)$. Below 300 mpcf.y, the SMR fluctuated around $1 \cdot 27$, with a strong suggestion from table 8 that this excess over expectation was largely explained by cigarette smoking. The data on which table 8 is based can be used for calculation of the relative asbestos effect ${ }^{12}$; many values can be obtained, depending on how "exposed" and "unexposed" are determined and even on the definitions of smokers and non-smokers, but all we have calculated were considerably greater than unity, the value that would arise if the asbestos-smoking interaction were multiplicative. Berry et $a l$, in a review of six studies, ${ }^{12}$ including our earlier report on cohort mortality to $1975,{ }^{5}$ found an average relative asbestos effect of 1.8 ; the figure we consider comparable is similar-namely, $1 \cdot 6$ (see footnote to table 8). This and the gradient in asbestos effects shown in table 8 provide further confirmation that the interaction between smoking and asbestos is less than multiplicative-and far from simple.

The risk of lung cancer in relation to exposure to asbestos and smoking cannot, however, be examined adequately by the subject-years method, even with Poisson regression analysis and despite the large number of events. It has become increasingly evident that the linear relations that have been found between SMRs and cumulative exposure are an oversimplification. Instead, forms of analysis are required that are capable of assessing the separate and combined effects of duration and intensity of exposure to asbestos, with appropriate allowance for a number of time related variables, ${ }^{6}{ }^{17}$ and with due regard to cigarette smoking. This work is now under way and will also be reported at a later date.

This report would have been impossible without the contributions of many agencies and people, in private or official capacity. We wish to mention in particular Mme Fernande Proulx, in Asbestos, and Mme Marie Beauchemin, of Thetford Mines, whofrom 1966 and 1969 respectively have maintained contact with the cohort, continuing the tracing to the end of 1992, and Mme Marielle Olivier, Senior Programmer, Department of Epidemiology and Biostatistics, McGill University, whose insight and skills have ensured the progress and integrity of the massive data processing effort. We also thank Dr Graham W Gibbs and Dr Patrick Sébastien for invaluable advice on assessment of dust exposure. A grant towards the costs of the research was made to McGill University by the National Health Research and Development Program of Health and Welfare Canada.

Requests for reprints to: Professor JC McDonald, National Heart and Lung Institute, Dovehouse Street, London SW3 6LY.

1 Working Group on Asbestos and Cancer. Report and recommendations of the Working Group convened under the auspices of the Geographical Pathology Committee of the International Union against Cancer. Ann NY Acad $\mathrm{Sci}$ 1965;132:706-21

2 McDonald JC, McDonald AD, Gibbs GW, Siemiatycki J, Rossiter CE. Mortality in the chrysotile asbestos mines and mills of Quebec. Arch Environ Health 1971;22:677-86.

3 McDonald JC, Rossiter CE, Eyssen GE, McDonald AD Mortality in the chrysotile producing industry of Quebec: a progress report. In: Gavrilescu N, ed. Proceedings of the IVth International Pneumoconiosis Conference, Bucharest, 1971. Bucharest: Apimondia, 1973:234-7. 
4 Liddell FDK, McDonald JC, Thomas DC. Methods of cohort analysis: appraisal by application to asbestos mining. fournal of the Royal Statistical Society Series A 1977;140:469-91.

5 McDonald JC, Liddell FDK, Gibbs GW, Eyssen GE, McDonald AD. Dust exposure and mortality in chrysotile mining, 1910-75. Br f Ind Med 1980;37:11-24.

6 Liddell FDK. Maintaining progress in the analysis of cohort studies. In: Hogstedt C, Reuterwall C, eds. Progress in occupational epidemiology. Amsterdam: Elsevier, 1988:71-4.

7 Peto J, Seidman H, Selikoff IJ. Mesothelioma mortality in asbestos workers: implications for models of carcinogenesis and risk assessment. $\mathrm{Br} \mathcal{F}$ Cancer 1982;45:124-35.

8 Gibbs GW, Lachance M. Dust exposure in the chrysotile asbestos mines and mills of Quebec. Arch Environ Health 1972;24:189-97.

9 Berry G. The analysis of mortality by the subject-years method. Biometrics 1983;39:173-84.

10 Coleman MP, Hermon C, Douglas A. Person-years (PYRS): a Fortran program for cohort study analysis. Lyon: International Agency for Research on Cancer, 1989. (Internal Report No 89/006.)

11 Goldberg M. Calculation of population mortality rates for the Province of Quebec, Rural Quebec and the Eastern Townships. Privately circulated, 1989.
12 Berry G, Newhouse ML, Antonis P. Combined effects of asbestos and smoking on mortality from lung cancer and mesothelioma in factory workers. $\mathrm{Br} F$ Ind Med 1985; 42:12-8.

13 Enterline PE, Hartley J, Henderson V. Asbestos and cancer: a cohort followed up to death. $\mathrm{Br}$ f Ind Med 1987;44: 396-401.

14 McDonald AD, Liddell FDK, McDonald JC. Malignant mesothelioma in Quebec chrystolite miners and millers: a preliminary report. In: Proceedings of the 9th International Symposium on Epidemiology in Occupational Health, Cincinnati, Ohio, September 1992. (In press.)

15 Selikoff IJ, Hammond EC, Seidman H. Mortality experience of insulation workers in the United States and Canada, 1943-1976. Ann NY Acad Sci 1979;330:91-116.

16 Sluis-Cremer GK, Liddell FDK, Logan WPD, Bezuidenhout BN. The mortality of amphibole miners in South Africa, 1946-80. Br f Ind Med 1992;49:566-75.

17 Vacek PM, McDonald JC. Risk assessment using exposure intensity: an application to vermiculite mining. $\mathrm{Br} \mathcal{F}$ Ind Med 1991;48:543-7.

Accepted 5 April 1993
Occupational and Environmental Medicine welcomes correspondence relating to any of the material appearing in the journal. Results from preliminary or small scale studies may also be published in the correspondence column if this seems appropriate. Letters should be not more than 500 words in length and contain a minimum of references. Tables and figures should be kept to an absolute minimum. Letters are accepted on the understanding that they may be subject to editorial revision and shortening.

The journal also publishes editorials which are normally specially commissioned. The Editor welcomes suggestions regarding suitable topics; those wishing to submit an editorial, however, should do so only after discussion with the Editor. 